\title{
Matrix metalloproteinase-3 gene polymorphism and its mRNA expression in rheumatoid arthritis
}

\author{
M.J. Ma' ${ }^{1}$ H.C. Liu $^{2}$, X.Q. Qu ${ }^{3}$ and J.L. Wang ${ }^{3}$ \\ ${ }^{1}$ Department of Surgery, Victory Hospital of China Petrochemical Group, \\ Victory Petroleum Administration, Dongying, Shandong, China \\ ${ }^{2}$ Department of Orthopedics, Affiliated Hospital of Weifang Medical University, \\ Weifang, Shandong, China \\ ${ }^{3}$ Orthopaedic Institute of PLA, 89th Hospital, Weifang, Shandong, China \\ Corresponding author: J.L. Wang \\ E-mail: linyexinx@163.com
}

Genet. Mol. Res. 14 (4): 15652-15659 (2015)

Received July 10, 2015

Accepted October 12, 2015

Published December 1, 2015

DOI http://dx.doi.org/10.4238/2015.December.1.17

\begin{abstract}
Matrix metalloproteinase-3 (MMP-3) can mediate the occurrence and development of rheumatoid arthritis (RA). The $M M P 3$ promoter gene exhibits polymorphism with $5 \mathrm{~A} / 6 \mathrm{~A}$ alleles. We investigated the correlation between the expression of MMP3 gene polymorphism and RA to provide an objective basis for prognosis evaluation. We enrolled 80 RA patients and 80 healthy subjects. Enzyme-linked immunosorbent assay was used to detect MMP-3 serum levels, pyrosequencing was used to test MMP3 genotypes, and realtime polymerase chain reaction determined MMP-3 mRNA expression levels. Compared with the control group, the serum level of MMP-3 in the RA patients increased significantly $(\mathrm{P}<0.05)$. The serum level of MMP-3 in RA patients in the active period was markedly elevated compared with that in patients in the relief period $(\mathrm{P}<0.05)$. There was no statistically significant difference between $M M P 3$ gene frequency distribution in the RA patients and the control group ( $\mathrm{P}>0.05)$. MMP-
\end{abstract}


3 mRNA expression in the RA patients was markedly upregulated compared with the control group $(\mathrm{P}<0.05)$, while RA patients in the active period exhibited higher MMP-3 mRNA expression $(\mathrm{P}<0.05)$. There was no significant difference in MMP-3 mRNA expression between RA patients with or without the 6A/6A genotype $(\mathrm{P}>$ 0.05). RA patients exhibited higher serum MMP-3 levels and mRNA expression, which were more obvious in the active period. MMP-3 is associated with the occurrence and development of RA bone erosion, and its serum level and mRNA expression can be treated as important predictors of joint damage.

Key words: Rheumatoid arthritis; Matrix metalloproteinase-3; Genetic polymorphism; mRNA expression

\section{INTRODUCTION}

The main pathological features of rheumatoid arthritis (RA) are synovitis and irreversible joint erosion (Zigouris et al., 2011). It has been shown that matrix metalloproteinases (MMPs), a family of enzymes that can degrade extracellular matrix proteins, can mediate the occurrence and development of RA (Klein and Bischoff, 2011). MMP-3 is the most important protease involved in cartilage degradation, and it can be activated by several cytokines such as interleukin-1 and tumor necrosis factor alpha. Following activation, MMP-3 can activate the other MMPs and degrade multiple proteins, such as cartilage link protein, fibronectin, and collagen types IV, VII, IX, and XI (Kobayashi et al., 2007). The serum level of MMP-3 shows significant correlation with several RA-related activity indicators, such as C-reactive protein (CRP) and erythrocyte sedimentation rate (ESR) (Yokoe et al., 2011). Although CRP and ESR are the products of systemic inflammatory reactions, they cannot directly represent the degree of inflammatory reaction in RA patients (Felson et al., 2011). However, MMP-3 cannot only indirectly participate in RA inflammation through degradation and dissolution, but can also directly degrade cartilage and bone (Mamehara et al., 2010). The MMP3 promoter gene exhibits polymorphism, with 5A/6A alleles (Urata, 2012) and correlation with RA. This study aimed to investigate the correlation between serum levels of MMP-3 and mRNA expression of the $M M P 3$ gene polymorphism and RA, to provide an objective basis for prognosis evaluation.

\section{MATERIAL AND METHODS}

\section{General information}

Between January 2013 and October 2014, 80 RA patients and 80 healthy subjects were enrolled. All RA patients were diagnosed in accordance with the RA classification standard modified by the 2009 American Rheumatism Association (ACR) and the European League Against Rheumatism (EULAR) (Aletaha et al., 2010). Patients with liver and kidney dysfunction, diabetes and metabolic abnormality disease, severe cardiac dysfunction, other joint diseases, malignant tumors, pregnancy, and lactation were excluded. The RA patients comprised 64 females and 16 males with an average age of $45.0 \pm 6.5$ (16.5-75) years; the control group comprised 62 females and 18 males with an average age of $45.2 \pm 6.7$ (17-75.5) years. No 
statistically significant difference was found in gender and age between the two groups $(\mathrm{P}>$ 0.05). Among the $80 \mathrm{RA}$ patients, 54 cases were in the active period and there were 26 cases of remission in the relief period.

\section{Index detection}

\section{Serum MMP-3 levels}

Venous blood was collected without anticoagulant and the serum was separated by centrifugation. Enzyme-linked immunosorbent assay (ELISA) was used to detect serum levels of MMP-3 according to the manufacturer instructions. The ELISA kit (E070120BL) was bought from the Zeus Company (USA), and the microplate reader was bought from BioTek (Synergy ${ }^{\mathrm{TM}}$ HT, USA).

\section{Peripheral blood genomic DNA and mononuclear cell RNA extraction}

Ficoll was used for the separation of peripheral blood mononuclear cells. The whole blood was diluted with phosphate-buffered saline at a ratio of 1:1, then Ficoll and the diluted whole blood were mixed at a ratio of $1: 1.5$. The mononuclear cells were separated by centrifugation at $2000 \mathrm{rpm}$ for $20 \mathrm{~min}$ at $20^{\circ} \mathrm{C}$. Total RNA from the identical densities of cells was isolated using guanidinium thiocyanate-phenol-chloroform extraction reagent (TRIzol reagent; Invitrogen) in the presence of $20 \mathrm{mg} / \mathrm{mL}$ linear acrylamide, according to the manufacturer instructions.

\section{Pyrosequencing}

Pyrosequencing (Galil et al., 2014) was used to detect polymorphism loci. Different genotypes were determined according to the base sequence detection. The GeneMapper software was applied for data analysis.

\section{Reverse transcription (RT)}

RT was conducted immediately after cell lysis. Total RNAs were reverse transcribed with RT mixtures containing $5 \mathrm{X}$ PrimeScript buffer $(2 \mu \mathrm{L})$, PrimeScript RT Enzyme Mix $(0.5$ $\mu \mathrm{L})$, oligo (dT) primer $(0.5 \mu \mathrm{L})$, and random 6-mers $(0.5 \mu \mathrm{L})$ in a total volume of $10 \mu \mathrm{L}$ for 15 min at $37^{\circ} \mathrm{C}$ and $5 \mathrm{~s}$ at $85^{\circ} \mathrm{C}$.

\section{Real-time RT polymerase chain reaction (RT-PCR)}

Each real-time RT-PCR (in $20 \mu \mathrm{L}$ ) contained $12.5 \mu \mathrm{L}$ SYBR Premix Ex Taq, $0.5 \mu \mathrm{L}$ forward primer, $0.5 \mu \mathrm{L}$ reverse primer, $2 \mu \mathrm{L}$ template cDNA, and $9.5 \mu \mathrm{L}$ distilled water. The cycling conditions comprised an initial, single cycle of $5 \mathrm{~s}$ at $95^{\circ} \mathrm{C}$, followed by 40 cycles of $5 \mathrm{~s}$ at $95^{\circ} \mathrm{C}$ and $30 \mathrm{~s}$ at $60^{\circ} \mathrm{C}$.

\section{$\boldsymbol{R} A$ activity determination criteria}

The RA activity determination criteria were: medium rest pain; morning stiffness for 
more than $1 \mathrm{~h}$; joint swelling $\geq 3$; joint tenderness points $>5$; and ESR $>28 \mathrm{~mm} / \mathrm{h}$ (Gorai et al., 2014).

\section{Statistical analysis}

Numerical data are reported as means and standard deviation $( \pm \mathrm{SD})$. Differences between means and rates were analyzed using one-way analysis of variance and the chi-square test, respectively. All statistical analyses were performed using the SPSS11.0 software (Chicago, IL, USA). P values $<0.05$ were considered to be statistically significant.

\section{RESULTS}

\section{MMP3 promoter 5A/6A allele determination}

After the samples had been subjected to PCR and sequenator electrophoresis, the GeneMapper software was used for data analysis. Three genotypes were found: MMP3 5A/5A, homozygous alleles with one peak at 125;MMP3 5A/6A, heterozygous alleles with peaks at 125 and 126; and MMP3 6A/6A, homozygous alleles with one peak at 126 (Figure 1).

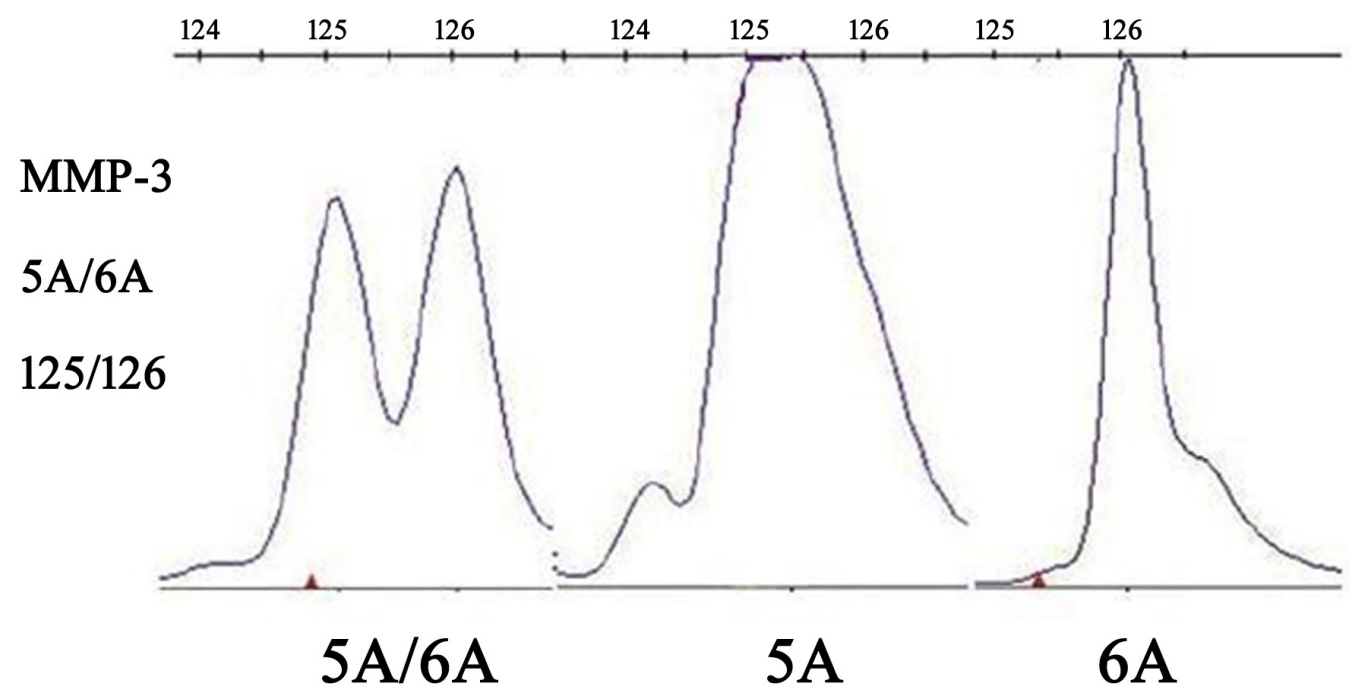

Figure 1. Matrix metalloproteinase-3 (MMP-3) (5A/6A) genotyping. Gene polymorphism loci exist in MMP-3 (5A/6A): homozygous, $5 \mathrm{~A} / 5 \mathrm{~A}$ and $6 \mathrm{~A} / 6 \mathrm{~A}$; and heterozygous, $5 \mathrm{~A} / 6 \mathrm{~A}$.

\section{MMP-3 serum level comparison}

Compared with the control group, the serum level of MMP-3 in RA patients increased significantly $(\mathrm{P}<0.05$; Table 1$)$. The serum level of MMP-3 in RA patients in the active period was markedly elevated compared with the patients in the relief period $(\mathrm{P}<0.05$; Table 2$)$. RA patients with the $6 \mathrm{~A} / 6 \mathrm{~A}$ genotype showed markedly higher serum levels of MMP-3 $(\mathrm{P}<0.05$; Table 3). 
Table 1. Comparison of matrix metalloproteinase-3 (MMP-3) serum levels in rheumatoid arthritis (RA) patients and healthy controls (means $\pm \mathrm{SD}, \mathrm{ng} / \mathrm{mL}$ ).

\begin{tabular}{lcc}
\hline Group & Cases & MMP-3 \\
\hline RA patients & 80 & $179.6 \pm 21.3$ \\
Healthy controls & 80 & $26.3 \pm 5.2$ \\
$t$-value & & 8.69 \\
P value & & $<0.05$ \\
\hline
\end{tabular}

Table 2. Comparison of matrix metalloproteinase-3 (MMP-3) serum levels in rheumatoid arthritis (RA) patients in the active period and in the relief period (means $\pm \mathrm{SD}, \mathrm{ng} / \mathrm{mL}$ ).

\begin{tabular}{lcc}
\hline Group & Cases & MMP-3 \\
\hline RA patients in active period & 54 & $233.4 \pm 34.7$ \\
RA patients in relief period & 26 & $77.5 \pm 12.3$ \\
$t$-value & & 7.42 \\
P value & & $<0.05$ \\
\hline
\end{tabular}

Table 3. Comparison of matrix metalloproteinase-3 (MMP-3) serum levels in rheumatoid arthritis (RA) patients with different genotypes (means $\pm \mathrm{SD}, \mathrm{ng} / \mathrm{mL}$ ).

\begin{tabular}{lcc}
\hline Group & Cases & MMP-3 \\
\hline $5 \mathrm{~A} / 5 \mathrm{~A}+5 \mathrm{~A} / 6 \mathrm{~A}$ group & 17 & $136.8 \pm 20.3$ \\
6A/6A group & 63 & $248.3 \pm 27.9$ \\
$t$-value & & 6.74 \\
P value & & $<0.05$ \\
\hline
\end{tabular}

\section{MMP3 gene polymorphism analysis}

There was no statistically significant difference in $M M P 3$ gene frequency distribution between the RA patients and the control group $(\mathrm{P}>0.05$; Table 4$)$.

Table 4. Comparison of metalloproteinase-3 gene (MMP3) frequency between the two groups (\%).

\begin{tabular}{lcccc}
\hline Group & Cases & $5 \mathrm{~A} / 5 \mathrm{~A}$ & $5 \mathrm{~A} / 6 \mathrm{~A}$ & $6 \mathrm{~A} / 6 \mathrm{~A}$ \\
\hline RA patients & 80 & $2(2.5 \%)$ & $14(17.5 \%)$ & $64(80.0 \%)$ \\
Healthy controls & 80 & $2(2.5 \%)$ & $15(18.75 \%)$ & $63(78.75 \%)$ \\
Chi-square value & & 0.00 & 0.04 & 0.04 \\
P value & & $>0.05$ & $>0.05$ & $>0.05$ \\
\hline
\end{tabular}

\section{MMP-3 mRNA expression level comparison}

MMP-3 mRNA expression in the RA patients was markedly upregulated compared with the control group $(\mathrm{P}<0.05$; Table 5); RA patients in the active period exhibited a higher level of MMP-3 mRNA expression than those in the relief period $(\mathrm{P}<0.05$; Table 6$)$. There was no significant difference in MMP-3 mRNA expression between RA patients with or without the $6 \mathrm{~A} / 6 \mathrm{~A}$ genotype $(\mathrm{P}>0.05$; Table 7$)$. 
Table 5. Comparison of matrix metalloproteinase-3 (MMP-3) mRNA expression between the two groups (means $\pm \mathrm{SD}$ ).

\begin{tabular}{lcc}
\hline Group & Cases & $\Delta$ Ct value \\
\hline RA patients & 80 & $1.31 \pm 0.12$ \\
Healthy controls & 80 & $0.92 \pm 0.21$ \\
$t$-value & & 3.14 \\
P value & & $<0.05$ \\
\hline
\end{tabular}

Table 6. Comparison of matrix metalloproteinase-3 (MMP-3) mRNA expression between rheumatoid arthritis (RA) patients in the active period and in the relief period (means $\pm \mathrm{SD}$ ).

\begin{tabular}{lcc}
\hline Group & Cases & $\Delta$ Ct value \\
\hline RA patients in active period & 54 & $1.02 \pm 0.21$ \\
RA patients in relief period & 26 & $0.80 \pm 0.19$ \\
$t$-value & & 3.06 \\
P value & & $<0.05$ \\
\hline
\end{tabular}

Table 7. Comparison of matrix metalloproteinase-3 (MMP-3) mRNA expression in rheumatoid arthritis (RA) patients with different genotypes (means $\pm \mathrm{SD}$ ).

\begin{tabular}{lcc}
\hline Group & Cases & $\Delta$ Ct value \\
\hline $5 \mathrm{~A} / 5 \mathrm{~A}+5 \mathrm{~A} / 6 \mathrm{~A}$ group & 17 & $0.92 \pm 0.23$ \\
$6 \mathrm{~A} / 6 \mathrm{~A}$ group & 63 & $0.93 \pm 0.24$ \\
$t$-value & & 0.03 \\
$\mathrm{P}$ value & & $>0.05$ \\
\hline
\end{tabular}

\section{DISCUSSION}

MMP-3 is mainly secreted by synovial cells, fibroblasts, and cartilage cells, but can also be secreted by osteoclasts in small amounts. MMP-3 can directly degrade proteoglycan in the extracellular matrix. When MMP enzymes are activated, MMP-3 is activated first. It then activates the zymogens of other MMPs, which leads to degradation of extracellular matrix components such as fiber adhesive proteins and laminin. This leads to MMP degradation products; mucopolysaccharides are released to the joints simultaneously and cause joint inflammation (Li et al., 2013; Ma et al., 2014; Sun et al., 2014). The major histocompatibility complex presents the fragments generated by MMP-3 hydrolysis of collagen to T cells, and promotes the activation and release of large amounts of inflammatory cytokines, which in turn increases MMP-3 expression levels in the cartilage cells and synovial fibroblasts. All these processes result in increased collagenase activity and aggravation of joint inflammation (Houseman et al., 2012; Lee et al., 2014). In addition, MMP-3 secreted into the synovial fluid can directly degrade the cartilage and bone composition without synovial membrane covering, thereby damaging the articular cartilage and bone of the RA patients (Ryu et al., 2011).

Previous research has suggested that clinical indicators commonly used for RA activity, such as CRP and ESR, cannot accurately reflect partial synovial inflammation and joint damage in RA patients. Therefore, it is necessary to seek a more sensitive and accurate indicator to evaluate and reflect the actual changes in RA patients (Kanbe et al., 2011). In the present study, compared with the control group, the serum level of MMP-3 in RA patients increased 
significantly $(\mathrm{P}<0.05)$. The serum level of MMP-3 in RA patients in the active period was markedly elevated compared with that of patients in the relief period $(\mathrm{P}<0.05)$. The results showed that MMP-3 is not only the key enzyme for synovial inflammatory reaction in RA patients, but can also cause joint damage. MMP-3 can be used for monitoring synovial inflammation in RA patients and evaluating the curative effect to guide further clinical application and treatment.

At the transcriptional level, MMP-3 expression is regulated by a promoter gene. Two alleles called $5 \mathrm{~A}$ and $6 \mathrm{~A}$ are located at position 1171 relative to the transcription start site in the human $M M P 3$ gene promoter region, and $5 \mathrm{~A} / 6 \mathrm{~A}$ polymorphism results in different gene transcription activity of $M M P 3$. The 5A homozygote protein expression level is four times higher than the $5 \mathrm{~A} / 6 \mathrm{~A}$ heterozygote protein level, while the $6 \mathrm{~A}$ homozygote protein level is only half that of the 5A/6A heterozygote protein (Urata, 2012). However, the effect of $M M P 3$ gene polymorphism on the occurrence and development of RA is still not clear. In our study, there was no statistically significant difference between the $M M P 3-1171$ locus $5 \mathrm{~A} / 6 \mathrm{~A}$ gene promoter single nucleotide polymorphism locus frequency distribution in the RA patients and the healthy controls $(\mathrm{P}>0.05)$. Furthermore, RA patients with the $6 \mathrm{~A} / 6 \mathrm{~A}$ genotype showed markedly higher serum levels of MMP-3 $(\mathrm{P}<0.05)$. The results suggest that the degree and rate of bone erosion damage are higher in RA patients with the $6 \mathrm{~A} / 6 \mathrm{~A}$ genotype. Thus, the $M M P 3$ 6A/6A genotype can be treated as a predicator of bone erosion severity in RA patients.

However, our research revealed no statistically significant differences in MMP-3 mRNA levels between the groups $(\mathrm{P}>0.05)$. Our results indicated that the three genotypes of single nucleotide polymorphism in the $5 \mathrm{~A} / 6 \mathrm{~A}$ gene promoter region $(-1171)$ had no correlation with RA occurrence, and this may be related to the multiple factors that influence MMP-3 mRNA expression. For example, inflammatory cytokine interleukin 1 and tumor necrosis factor alpha can upregulate MMP-3 mRNA expression, while interleukin-4 and tumor necrosis factor beta can downregulate it (Nagasawa et al., 2010). Drug treatment and the disease itself may change some related cytokine expression levels, affecting MMP-3 mRNA expression and the occurrence and development of RA (Kotani et al., 2012; Hiura et al., 2013).

In conclusion, the RA patients exhibited higher MMP-3 mRNA expression, and it was more obvious in the active period of the disease. MMP-3 mRNA expression is associated with the occurrence and development of RA.

\section{Conflicts of interest}

The authors declare no conflict of interest.

\section{ACKNOWLEDGMENTS}

We thank the anonymous reviewers for reviewing this manuscript. Research supported by grants from the Science and Technology Development Program of Weifang in China (\#201301074)

\section{REFERENCES}

Aletaha D, Neogi T, Silman AJ, Funovits J, et al. (2010). 2010 Rheumatoid arthritis classification criteria: an American College of Rheumatology/European League Against Rheumatism collaborative initiative. Arthritis Rheum. 62: 2569-2581. 
Felson DT, Smolen JS, Wells G, Zhang B, et al. (2011). American College of Rheumatology/European League against Rheumatism provisional definition of remission in rheumatoid arthritis for clinical trials. Ann. Rheum. Dis. 70: 404413.

Galil SM, El-Shafey AM, Hagrass HA, Fawzy F, et al. (2014). Baseline serum level of matrix metalloproteinase-3 as a biomarker of progressive joint damage in rheumatoid arthritis patients. Int. J. Rheum. Dis. Doi: 10.1111/1756185X.12434. [Epub ahead of print]

Gorai M, Ogasawara M, Matsuki Y, Yamada Y, et al. (2014). Weighting with the Lansbury articular index improves the correlation of ultrasound score with serum matrix metalloproteinase-3 level in rheumatoid arthritis patients. Mod. Rheumatol. 24: 915-919.

Hiura K, Iwaki-Egawa S, Kawashima T, Fujisawa S, et al. (2013). The diagnostic utility of matrix metalloproteinase-3 and high-sensitivity C-reactive protein for predicting rheumatoid arthritis in anti-cyclic citrullinated peptide antibodynegative patients with recent-onset undifferentiated arthritis. Rheumatol. Int. 33: 2309-2314.

Houseman M, Potter C, Marshall N, Lakey R, et al. (2012). Baseline serum MMP-3 levels in patients with Rheumatoid Arthritis are still independently predictive of radiographic progression in a longitudinal observational cohort at 8 years follow up. Arthritis Res. Ther. 14: R30.

Kanbe K, Chiba J and Nakamura A (2011). Decrease of CD68 and MMP-3 expression in synovium by treatment of adalimumab for rheumatoid arthritis. Int. J. Rheum. Dis. 14: 261-266.

Klein T and Bischoff R (2011). Physiology and pathophysiology of matrix metalloproteases. Amino Acids 41: 271-290.

Kobayashi A, Naito S, Enomoto H, Shiomoi T, et al. (2007). Serum levels of matrix metalloproteinase 3 (stromelysin 1) for monitoring synovitis in rheumatoid arthritis. Arch. Pathol. Lab. Med. 131: 563-570.

Kotani T, Takeuchi T, Takai S, Shuzo Yoshida, et al. (2012). Serum levels of matrix metalloproteinase (MMP) 9, a risk factor for acute coronary syndrome, are reduced independently of serum MMP-3 by anti-TNF-alpha antibody (infliximab) therapy in patients with rheumatoid arthritis. J. Pharmacol. Sci. 120: 50-53.

Lee A, Park K, Choi SJ, Seo DH, et al. (2014). Prediction of antiarthritic drug efficacies by monitoring active matrix metalloproteinase-3 (MMP-3) levels in collagen-induced arthritic mice using the MMP-3 probe. Mol. Pharm. 11: $1450-1458$.

Li L, Cai B, Liao J, Yang B, et al. (2013). Clinical value of serum matrix metalloproteinase-3 in evaluating joint destruction and therapeutic effect in rheumatoid arthritis patients. Xi Bao Yu Fen Zi Mian Yi Xue Za Zhi 29: 966-969.

Ma JD, Zhou JJ, Zheng DH, Le-Feng Chen, et al. (2014). Serum matrix metalloproteinase-3 as a noninvasive biomarker of histological synovitis for diagnosis of rheumatoid arthritis. Mediators Inflamm. 2014: 179284.

Mamehara A, Sugimoto T, Sugiyama D, Morinobu S, et al. (2010). Serum matrix metalloproteinase-3 as predictor of joint destruction in rheumatoid arthritis, treated with non-biological disease modifying anti-rheumatic drugs. Kobe J. Med. Sci. 56: E98-107.

Nagasawa H, Kameda H, Sekiguchi N, Amano K, et al. (2010). Normalisation of physical function by infliximab in patients with RA: factors associated with normal physical function. Clin. Exp. Rheumatol. 28: 365-372.

Ryu JH, Lee A, Chu JU, Koo H, et al. (2011). Early diagnosis of arthritis in mice with collagen-induced arthritis, using a fluorogenic matrix metalloproteinase 3-specific polymeric probe. Arthritis Rheum. 63: 3824-3832.

Sun S, Bay-Jensen AC, Karsdal MA, Siebuhr AS, et al. (2014). The active form of MMP-3 is a marker of synovial inflammation and cartilage turnover in inflammatory joint diseases. BMC Musculoskelet. Disord. 15: 93.

Urata Y, Uesato R, Tanaka D, Nakamura Y, et al. (2012). Treating to target matrix metalloproteinase 3 normalisation together with disease activity score below 2.6 yields better effects than each alone in rheumatoid arthritis patients: T-4 Study. Ann Rheum Dis. 71: 534-540.

Yokoe I, Nishio S, Sato H and Hitomi Kobayashi (2011). Comparison of MMP-3 levels in rheumatoid arthritis after treatment with tocilizumab or infliximab for 12 weeks. Mod. Rheumatol. 21: 710-714.

Zigouris A, Batistatou A, Alexiou GA, Pachatouridis D, et al. (2011). Correlation of matrix metalloproteinases-1 and -3 with patient age and grade of lumbar disc herniation. J. Neurosurg. Spine 14: 268-272. 